\title{
CT Image Artifact
}

National Cancer Institute

\section{Source}

National Cancer Institute. CT Image Artifact. NCI Thesaurus. Code C87009.

An artifact in a CT image. 